\title{
PENGARUH BOOKLET HIGIENE DAN SANITASI TERHADAP TINDAKAN PENCEGAHAN KECACINGAN PADA SISWA SEKOLAH DASAR DI WILAYAH DESA TENGANAN KABUPATEN KARANGASEM TAHUN 2020
}

\author{
I Made Bulda Mahayana
}

\begin{abstract}
Worms infection in Bali Province is still a disease that is a public health problem. The purpose of this study was to determine the effect of the use of hygiene and sanitation booklets on worm disease prevention measures in elementary school students in the village area of Tenganan, Karangasem Regency. This study used a true experimental design with a pretestposttest control group design method. The sample consisted of 51 students in the control group and 51 students in the treatment group. Data analysis used paired sample t-test and independent samples t-test. The results of student assessments of hygiene and sanitation used paired sample ttest analysis of the control group $p<0.05$, while the analysis results in the treatment group were $p<0.05$. Furthermore, the results of the analysis of independent samples $t$-test on the post-test of the control group and the treatment group for hygiene obtained $p<0.005$ and $p<0.05$ for sanitation. So it can be concluded that there is an effect of the use of hygiene and sanitation booklets on the prevention of worm disease in elementary school students in the village of Tenganan, Karangasem Regency. Recommendations to primary school principals that this "Handworm Hygiene and Sanitation Measures Booklet" can be used as a reference in physical education and health subjects.
\end{abstract}

Keywords: Sanitation, Hygiene, Booklet, Worms

\section{PENDAHULUAN}

Infeksi kecacingan sampai saat ini masih merupakan penyakit yang menjadi masalah kesehatan masyarakat di Indonesia karena berjangkit di sebagian besar wilayah Indonesia dan dapat mengakibatkan menurunnya kondisi kesehatan, gizi, kecerdasan, dan produktifitas (1).

Infeksi kecacingan tergolong penyakit neglected disease yaitu infeksi yang kurang diperhatikan dan penyakitnya bersifat kronis tanpa menimbulkan gejala klinis yang jelas dan dampak yang ditimbulkannya baru terlihat dalam jangka panjang seperti kasus

stanting karena kekurangan asupan gizi, gangguan kognitif dan gangguan tumbuh kembang pada anak. Selain itu infeksi kecacingan dapat menimbulkan kerentanan terhadap penyakit penting lainnya, seperti penyakit malaria, TBC Paru, Diare dan Anemia (2). Faktor-faktor yang berpengaruh 
terhadap kejadian kecacingan antara lain : faktor sosial ekonomi, status gizi, penataan kesehatan lingkungan, higenitas, sanitasi, pendidikan dan perilaku individu. Hasil penelitian di Ethiophia menyebutkan bahwa faktor sosial ekonomi yang rendah dan sanitasi yang buruk merupakan penyebab utama terjadinya infeksi cacing usus (3). Selain faktor-faktor di atas faktor kepemilikan jamban keluarga juga sangat berpengaruh (4). Menurut Permenkes 15 Tahun 2017 salah satu penyelenggaraan kegiatan penanggulangan kecacingan dapat dilaksanakan kegiatan pengendalian faktor risiko melalui dua kegiatan utama yaitu menjaga kebersihan perorangan (Higiene) dan menjaga kebersihan lingkungan (Sanitasi) (1).

Penelitian lain menyebutkan bahwa faktor perilaku higienitas dan sanitasi sekolah mempunyai peran penting terjadinya infeksi soil transmitted helminths pada siswa Sekolah Dasar Negeri No 5 Delod Peken Tabanan (5).

Khusus di Provinsi Bali sampai saat ini, secara nasional angka prevalensi

\section{METODE}

Penelitian pengaruh booklet higiene dan sanitasi terhadap tindakan pencegahan kecacingan pada siswa sekolah dasar di cacingan masih dalam kelompok sedang yang masuk kisaran 20-40 persen, tepatnya $24 \%$, untuk itu pemerintah daerah perlu melakukan upaya pengendalian penyakit kecacingan secara maksimal dengan sosialisasi dan advokasi serta koordinasi secara terpadu melalui kegiatan lintas program. Menekan prevalensi penyakit cacingan tidak bisa hanya mengandalkan pemberian obat cacing semata, namun perlu kesadaran masyarakat untuk menerapkan higiene dan sanitasi melalui melaksanakan perilaku hidup bersih dan sehat.

Berdasarkan hasil survei yang dilakukan oleh Dinas Kesehatan Provinsi Bali di lima daerah di Provinsi Bali Kabupaten Karangasen dan Buleleng kasus penyakit kecacingannya masih tinggi. Kasus tinggi cenderung di daerah kondisi lingkungannya buruk, ditunjang dengan tingkat kesadaran masih rendah akan masalah kecacingan. Hal ini dibuktikan dengan hasil penelitian di SD Negeri 3 Tenganan Kabupaten Karangasem menunjukkan bahwa masih ada 16 persen siswa yang fesesnya positif telur cacing (6).

wilayah Desa Tenganan Kabupaten Karangasem merupakan penelitian True Experimental Design dengan pendekatan rancangan Pretest - Posttest Control Group Design. Desain ini terdapat dua 
kelompok secara random, kemudian diberi pretest untuk mengetahui keadaan awal adakah perbedaan antara kelompok eksperimen yang diberi perlakuan booklet dan kelompok kontrol yang tidak diberi booklet. Hasil pretest yang baik bila nilai kelompok eksperimen tidak berbeda secara signifikan.

Lokasi penelitian ini dilaksanakan di lima sekolah dasar yang berada di wilayah Desa Tenganan Kecamatan Manggis Kabupaten Karangasem. Sedangkan waktu pelaksanaan penelitian dari bulan Juli 2020 sampai dengan bulan November 2020 . Populasi dalam penelitian ini ditetapkan adalah semua siswa kelas tiga dan empat sekolah dasar yang berada di wilayah Desa Tenganan Kecamatan Manggis Kabupaten Karangasem. sebanyak 140 orang. Sampel penelitian adalah siswa kelas tiga dan empat sekolah dasar yaitu sebanyak 140 orang. Dengan kriteria adalah sebagai berikut:

a. Bersedia sebagai responden

b. Bisa membaca dan menulis

c. Tidak dalam keadaan sakit

d. Bersedia dikunjungi rumah tinggalnya

Besar sampel atau jumlah sampel dihitung dengan cara menghitung jumlah sampel dari populasi yang telah diketahui jumlahnya dengan menggunakan rumus dari Isaac dan Michael pada tingkat kesalahan 5\% diperoleh besar sampel yang diambil adalah 102 sampel.

\section{HASIL}

\section{Deskripsi data}

Penelitian ini dilaksanakan pada sekolah dasar di wilayah Desa Tenganan Kabupaten Karangasem dan respondennya adalah siswa kelas tiga dan empat. Dalam penelitan ini melibatkan dua kelompok siswa yaitu kelompok kontrol dan kelompok perlakuan. Siswa kelompok kontrol penyampaian pesan tentang higiene dan sanitasi sebagai upaya pencegahan kecacingan dengan metode kompensional yaitu ceramah, sedangkan pada siswa kelompok perlakuan menggunakan booklet tentang higiene dan sanitasi pencegahan kecacingan untuk dipelajari secara mandiri. a. Jenis kelamin

Tabel 1

Distribusi Kelompok Siswa Berdasarkan Jenis Kelamin

\begin{tabular}{lcccc}
\hline \multirow{2}{*}{$\begin{array}{l}\text { Jenis } \\
\text { Kelamin }\end{array}$} & \multicolumn{3}{c}{ Kelompok Siswa } \\
\cline { 2 - 5 } & \multicolumn{2}{c}{ Kontrol } & \multicolumn{2}{c}{ Perlakuan } \\
\hline Laki-Laki & Jumlah & $\%$ & Jumlah & $\%$ \\
\hline Perempuan & 22 & 43,1 & 23 & 45,1 \\
\hline Total & 51 & 56,9 & 28 & 54,9 \\
\hline
\end{tabular}

Dari tabel 1 di atas menunjukkan bahwa pada kedua kelompok penelitian jumlah siswa berjenis kelamin perempuan lebih banyak daripada siswa laki-laki, yaitu 
pada kelompok kontrol sebanyak 29 siswa $(56,9 \%)$ dan kelompok perlakuan sebanyak 28 siswa $(54,9 \%)$.

b. Pekerjaan orang tua

\section{Tabel 2}

Distribusi Kelompok Siswa Berdasarkan Pekerjaan Orang Tua Siswa

\begin{tabular}{lcccc}
\hline & \multicolumn{4}{c}{ Kelompok Siswa } \\
\cline { 2 - 5 } Pekerjaan & \multicolumn{2}{c}{ Kontrol } & \multicolumn{2}{c}{ Perlakuan } \\
\cline { 2 - 5 } $\begin{array}{l}\text { Orang Tua } \\
\text { Siswa }\end{array}$ & Jumlah & $\%$ & Jumlah & $\%$ \\
\hline Buruh & 15 & 29,4 & 15 & 29,4 \\
\hline Dagang & 4 & 7,8 & 2 & 3,9 \\
\hline Pegawai & 2 & 3,9 & 3 & 5,9 \\
\hline Petani & 2 & 3,9 & 2 & 3,9 \\
\hline Swasta & 10 & 19,6 & 12 & 23,5 \\
\hline Tukang & 0 & 0 & 1 & 2,0 \\
\hline Wirausaha & 10 & 35,3 & 16 & 31,4 \\
\hline Total & 51 & 100 & 51 & 100 \\
\hline
\end{tabular}

Dari tabel 2 di atas menunjukkan bahwa pada kedua kelompok penelitian jenis pekerjaan orang tua paling banyak jumlahnya adalah sebagai wirausaha seperti sebagai pengrajin, yaitu pada kelompok kontrol sebanyak 10 siswa $(35,3 \%)$ dan kelompok perlakuan sebanyak 16 siswa $(31,4 \%)$.

c. Informasi pemeriksaan telur cacing

Tabel 3

\section{Distribusi Kelompok Siswa Berdasarkan} Informasi Pemeriksaan Telur Cacing

\begin{tabular}{lcccc}
\hline & \multicolumn{4}{c}{ Kelompok Siswa } \\
\cline { 2 - 5 } Pemeriksaan & \multicolumn{2}{c}{ Kontrol } & \multicolumn{2}{c}{ Perlakuan } \\
\cline { 2 - 5 } Telur Cacing & Jumlah & $\%$ & Jumlah & $\%$ \\
\hline Sudah Pernah & 14 & 27,5 & 13 & 25,5 \\
\hline Belum & 37 & 72,5 & 38 & 74,5 \\
Pernah & & & & \\
\hline Total & 51 & 100 & 51 & 100 \\
\hline
\end{tabular}

Dari tabel 3 di atas menunjukkan bahwa pada kedua kelompok penelitian jumlah siswa yang belum pernah diperiksa telur cacing pada tinjanya jumlahnya paling banyak, yaitu pada kelompok kontrol sebanyak 37 siswa $(72,5 \%)$ dan kelompok perlakuan sebanyak 38 siswa $(74,5 \%)$.

d. Informasi Minum obat cacing

Tabel 4

Distribusi Kelompok Siswa Berdasarkan Informasi Pernah Minum Obat Cacing

\begin{tabular}{lcccc}
\hline \multirow{2}{*}{$\begin{array}{l}\text { Minum } \\
\text { Obat }\end{array}$} & \multicolumn{4}{c}{ Kelompok Siswa } \\
\cline { 2 - 5 } Cacing & \multicolumn{2}{c}{ Kontrol } & \multicolumn{2}{c}{ Perlakuan } \\
\cline { 2 - 5 } & Jumlah & $\%$ & Jumlah & $\%$ \\
\hline $\begin{array}{l}\text { Sudah } \\
\text { Pernah }\end{array}$ & 47 & 92,2 & 48 & 94,1 \\
\hline $\begin{array}{l}\text { Belum } \\
\text { Pernah }\end{array}$ & 4 & 7,8 & 3 & 5,9 \\
\hline Total & 51 & 100 & 51 & 100 \\
\hline
\end{tabular}

Dari tabel di atas menunjukkan bahwa pada kedua kelompok sudah pernah minum obat cacing jumlahnya paling banyak, yaitu kelompok kontrol sebanyak 47 siswa $(92,2 \%)$ dan kelompok perlakuan sebanyak 48 siswa $(94,1 \%)$.

e. Higiene dan sanitasi kelompok kontrol

Tabel 5

Distribusi Nilai Rata-Rata Sebelum-Sesudah Intervensi Pada Kelompok Kontrol

\begin{tabular}{lllll}
\hline Variabel & Intervensi & Mean & $\mathrm{N}$ & Std. Dev \\
& & & & \\
\hline Higiene & Sebelum & 78.3333 & 51 & 7.59386 \\
\cline { 2 - 5 } & Sesudah & 83.2353 & 51 & 7.79894 \\
\hline Sanitasi & Sebelum & 76.2745 & 51 & 5.73089 \\
\cline { 2 - 5 } & Sesudah & 81.3725 & 51 & 5.57480 \\
\hline
\end{tabular}


Dari tabel di atas menunjukkan bahwa nilai rata-rata sesudah intervensi pada kelompok kontrol tindakan higiene 83,23 dan sanitasi 81,37 memiliki nilai lebih besar dibandingkan dengan nilai sebelum intervensi,

f. Higiene dan sanitasi kelompok perlakukan Tabel 6

Distribusi Nilai Rata-Rata Sebelum-Sesudah Intervensi Pada Kelompok Perlakuan

\begin{tabular}{llccc}
\hline Variabel & Intervensi & Mean & N & Std. Dev \\
\hline Higiene & Sebelum & 81.0784 & 51 & 5.22625 \\
\cline { 2 - 5 } & Sesudah & 88.3333 & 51 & 5.71548 \\
\hline Sanitasi & Sebelum & 82.3529 & 51 & 6.19298 \\
\cline { 2 - 5 } & Sesudah & 88.2353 & 51 & 6.84277 \\
\hline
\end{tabular}

Dari tabel di atas menunjukkan bahwa nilai rata-rata sesudah intervensi pada kelompok perlakuan tindakan higiene 88,33 dan sanitasi 88,23 memiliki nilai lebih besar dibandingkan dengan nilai sebelum intervensi

\section{Persyaratan data}

a. Uji normalitas

Uji normalitas menggunakan rumus Kolmogorof Smirnov Test. Untuk mengetahui normal tidaknya suatu data jika Asymp.sig (2-tailed) > 0,05 maka data disebut normal.
Tabel 7

Hasil Uji Normalitas Data Pre-Test dan Post-Test

\begin{tabular}{|l|c|c|c|}
\hline Variabel & $\begin{array}{c}\text { Asymp. } \\
\text { Sig (2- } \\
\text { tailed) }\end{array}$ & $\alpha$ & Interpretasi \\
\hline $\begin{array}{l}\text { Pre-test Higiene } \\
\text { K Kontrol }\end{array}$ & 0,303 & 0,05 & Normal \\
\hline $\begin{array}{l}\text { Post-test Higiene } \\
\text { K Kontrol }\end{array}$ & 0,248 & 0,05 & Normal \\
\hline $\begin{array}{l}\text { Pre-test Higiene } \\
\text { K Perlakuan }\end{array}$ & 0,060 & 0,05 & Normal \\
\hline $\begin{array}{l}\text { Post-test Higiene } \\
\text { K Perlakuan }\end{array}$ & 0,059 & 0,05 & Normal \\
\hline $\begin{array}{l}\text { Pre-test Sanitasi } \\
\text { K Kontrol }\end{array}$ & 0,093 & 0,05 & Normal \\
\hline $\begin{array}{l}\text { Post-test Sanitasi } \\
\text { K Kontrol }\end{array}$ & 0,056 & 0,05 & Normal \\
\hline $\begin{array}{l}\text { Pre-test Sanitasi } \\
\text { K Perlakuan }\end{array}$ & 0,158 & 0,05 & Normal \\
\hline $\begin{array}{l}\text { Post-test Sanitasi } \\
\text { K Perlakuan }\end{array}$ & 0,098 & 0,05 & Normal \\
\hline
\end{tabular}

Berdasarkan tabel 7 di atas hasil uji normalitas dengan rumus Kolmogorof Smirnov Test menunjukkan bahwa semua data pre-test dan post-test variabel tindakan higiene dan sanitasi pada kelompok kontol dan kelompok perlakuan memiliki nilai Asymp.Sig (2-tailed) $>\alpha=0,05$ atau $(\mathrm{p}>0,05)$, maka semua data berdistribusi normal atau mendekati normal.

b. Uji homogenitas

Uji homogenitas bertujuan untuk mengetahui apakah data yang diperoleh dari kedua kelompok memiliki varian yang homogen atau tidak. Untuk menguji homogenitas dapat menganalisis dengan menggunakan Levene's Test. Untuk mengetahui homogen tidaknya suatu data 
adalah jika Sig > 0,05 maka data dikatakan memiliki varian homogen, sebaliknya jika Sig $<0,05$ dapat dikatakan data memiliki varian tidak homogen.

\section{Tabel 8}

Uji Homogenitas Data Post-Test Tindakan Higiene dan Sanitasi Pada Kelompok Kontrol dan Kelompok Perlakuan

\begin{tabular}{cccc}
\hline Variabel & Sig & $\alpha$ & Interpretasi \\
\hline Higiene & 0,146 & 0,05 & Homogen \\
\hline Sanitasi & 0,078 & 0,05 & Homogen \\
\hline
\end{tabular}

Berdasarkan tabel 8 di atas dari hasil uji homogenitas dengan rumus Levene's Test menunjukkan bahwa data variabel tindakan higiene post-test kelompok kontrol dan perlakuan diperoleh Sig $=0,146>\alpha=$ 0,05 dan untuk variabel tindakan sanitasi post-test kelompok kontrol dan perlakuan diperoleh Sig $=0,078>\alpha=0,05$. Maka data variabel tindakan higiene dan sanitasi post-test kelompok kontrol dan kelompok perlakuan memiliki interpretasi data variannya homogen $(\mathrm{p}>0,05)$.

\section{Pengujian hipotesis}

Penelitian ini bertujuan untuk mengetahui pengaruh booklet tindakan higiene dan sanitasi terhadap pencegahan kecacingan pada siswa sekolah dasar di wilayah Desa Tenganan Kabupaten Karangasem. Analisis yang digunakan adalah Independent Samples T-Test terhadap data post-test variabel tindakan higiene dan sanitasi kelompok kontrol dan data post-test variabel tindakan higiene dan sanitasi kelompok perlakuan. Untuk mengetahui ada tidaknya perbedaan yang signifikan antara data post-test variabel tindakan higiene dan sanitasi kelompok kontrol dan kelompok perlakuan dengan Sig (2-tailed) > 0,05 maka data kedua kelompok dikatakan memiliki nilai rata-rata sama, sebaliknya jika Sig (2-tailed) < 0,05 dapat dikatakan data kedua kelompok memiliki rata-rata berbeda.

Tabel 9

Uji-T Data Post-Test Variabel Tindakan Higiene dan Sanitasi Pada Kelompok Kontrol dan Kelompok Perlakuan

\begin{tabular}{lcccc}
\hline $\begin{array}{l}\text { Variabel } \\
\text { Kelompok }\end{array}$ & $\begin{array}{c}\text { Rata- } \\
\text { Rata }\end{array}$ & $\begin{array}{c}\text { Sig } \\
(2 \text { tailed })\end{array}$ & $\alpha$ & Interpretasi \\
\cline { 1 - 2 } Higiene & 83,23 & 0,000 & 0,05 & Berbeda \\
Kontrol & & & & \\
\cline { 1 - 2 } $\begin{array}{l}\text { Higiene } \\
\text { Perlakuan }\end{array}$ & 88,33 & & & \\
\cline { 1 - 2 } $\begin{array}{l}\text { Sanitasi } \\
\text { Kontrol }\end{array}$ & 81,37 & 0,000 & 0,05 & Berbeda \\
\cline { 1 - 2 } $\begin{array}{l}\text { Sanitasi } \\
\text { Perlakuan }\end{array}$ & 88,23 & & & \\
\hline
\end{tabular}

Berdasarkan tabel 9 di atas diketahui hasil post-test rata-rata nilai tindakan higiene pada kelompok kontrol sebanyak 83,23 dan rata-rata nilai tindakan higiene kelompok perlakuan sebanyak 88,33 . Hal ini menunjukkan bahwa rata-rata nilai tindakan higiene pada kelompok perlakuan lebih besar dibandingkan dengan rata-rata nilai tindakan higiene kelompok kontrol, yang nilai lebihnya sebanyak 5,10 atau $6,13 \%$. Sedangkan rata-rata nilai tindakan sanitasi pada kelompok kontrol sebanyak 81,37 dan rata-rata nilai tindakan sanitasi kelompok perlakuan sebanyak 88,23. Hal ini menunjukkan bahwa rata-rata nilai tindakan sanitasi pada kelompok perlakuan lebih besar dibandingkan dengan rata-rata nilai 
tindakan sanitasi kelompok kontrol, yang nilai lebihnya sebanyak 6,86 atau $8,43 \%$.

Selanjutnya dari tabel di atas diperoleh untuk variabel tindakan higiene Sig (2-tailed) atau $\mathrm{p}=0,000$ dan $\alpha=0,05$ $(\mathrm{p}<0,05)$ berarti terdapat perbedaan nilai tindakan higiene pada kelompok kontrol dan kelompok perlakuan. Sedangkan untuk variabel tindakan sanitasi diperoleh $\mathrm{Sig}(2-$ tailed) atau $\mathrm{p}=0,000$ dan $\alpha=0,05(\mathrm{p}<0,05)$ berarti terdapat perbedaan nilai tindakan sanitasi pada kelompok kontrol dan kelompok perlakuan. Sehingga dapat disimpulkan bahwa terdapat perbedaan yang signifikan nilai tindakan sanitasi dan sanitasi siswa yang diberikan Booklet "Tindakan Higiene Dan Sanitasi Pencegahan Kecacingan" dengan siswa yang tidak diberikan booklet atau hanya diberikan ceramah singkat terkait pencegahan kecacingan.

\section{PEMBAHASAN}

Berdasarkan hasil penelitian terdapat perbedaan tindakan pencegahan kecacingan antara siswa yang diberikan booklet tindakan higiene dan sanitasi dengan siswa yang tidak diberikan booklet atau diberikan ceramah singkat terkait kecacingan. Kemampuan pencegahan kecacingan pada siswa yang memperoleh booklet tindakan higiene dan sanitasi, memiliki kemampuan lebih baik daripada siswa yang tidak diberikan booklet tindakan higiene dan sanitasi atau hanya diberikan ceramah singkat terkait kecacingan.

Bagi siswa yang mendapatkan booklet tindakan higiene dan sanitasi pencegahan kecacingan dapat lebih mampu melakukan pencegahan kecacingan, karena dalam proses pembelajaran berlangsung lebih lama dan berulang-ulang membaca booklet sehingga siswa mampu dengan benar menjawab pertanyaan tindakan pencegahan kecacingan pada saat post-test. Sedangkan pemahaman siswa tentang pencegahan kecacingan melalui materi ceramah singkat yang disampaikan tim peneliti menjadikan siswa mengalami kesulitan mengingat dan sangat tergantung dengan kemampuan intelektual masing-masing siswa. Keadaan ini menjadikan siswa yang diberikan booklet memiliki pengalaman dan kemampuan lebih dalam melakukan tindakan pencegahan kecacingan dibandingkan dengan siswa yang tidak diberikan booklet.

\section{Tindakan Higiene}

Berdasarkan hasil post-test rata-rata nilai tindakan higiene pada kelompok kontrol diperoleh sebanyak 83,23 dan ratarata nilai kelompok perlakuan sebanyak 88,33 . Hal ini menunjukkan bahwa rata-rata 
nilai tindakan higiene pada kelompok perlakuan lebih besar dibandingkan dengan rata-rata nilai tindakan higiene kelompok kontrol, yang selisih nilai lebihnya sebanyak 5,10 atau $6,13 \%$. Untuk mengetahui perbedaan dari kedua kelompok analisis yang digunakan adalah Independent Samples T-Test terhadap data post-test variabel tindakan higiene kelompok kontrol dan data post-test variabel tindakan higiene kelompok perlakuan. Hasil analisis diperoleh untuk variabel tindakan higiene $\mathrm{Sig}$ (2-tailed) $\mathrm{p}<0,05$ berarti terdapat perbedaan nilai tindakan higiene pada kelompok kontrol dan kelompok perlakuan. Sehingga dapat disimpulkan bahwa terdapat perbedaan yang signifikan nilai tindakan higiene siswa yang diberikan booklet dengan siswa yang tidak diberikan booklet atau diberikan ceramah singkat terkait kecacingan.

\section{Tindakan Sanitasi}

Hasil post-test rata-rata nilai tindakan sanitasi pada kelompok kontrol sebanyak 81,37 dan rata-rata nilai tindakan sanitasi pada kelompok perlakuan sebanyak 88,23. Hal ini menunjukkan bahwa rata-rata nilai tindakan sanitasi pada kelompok perlakuan lebih besar dibandingkan dengan rata-rata nilai tindakan sanitasi pada kelompok kontrol, yang selisih nilai lebihnya sebanyak 6,86 atau $8,43 \%$. Untuk mengetahui ada tidaknya perbedaan kedua kelompok maka analisis yang digunakan adalah Independent Samples T-Test terhadap data post-test variabel tindakan sanitasi kelompok kontrol dan data post-test variabel tindakan sanitasi kelompok perlakuan. Hasil analisis diperoleh untuk variabel tindakan sanitasi Sig (2-tailed) $\quad \mathrm{p}<0,05$ berarti terdapat perbedaan nilai tindakan sanitasi pada kelompok kontrol dan kelompok perlakuan. Sehingga dapat disimpulkan bahwa terdapat perbedaan yang signifikan nilai tindakan sanitasi siswa yang diberikan booklet dengan siswa yang tidak diberikan booklet atau diberikan ceramah singkat terkait kecacingan.

\section{Booklet}

Booklet dengan judul "Tindakan Higiene Dan Sanitasi Pencegahan Kecacingan" ini telah dihasilkan melalui prosedur penyusunan secara sistematis sesuai dengan kaidah ilmiah. Booklet ini sangat sesuai dengan kondisi sasaran karena disusun berdasarkan kebutuhan spesifikasi yang diinginkan baik dari segi desain grafis maupun materi yang disajikan dalam booklet ini disusun berdasarkan sumbersumber yang mutakhir berupa buku dan jurnal. Faktor yang perlu diperhatikan dalam pembuatan buku saku didasarkan pada kebutuhan sasaran maka dapat dikatakan 
bahwa booklet ini disusun tidak didasarkan atas kesenangan pribadi peneliti (7). Sedangkan peneliti lain yang menyatakan bahwa suatu media promosi kesehatan dikatakan baik harus apabila telah memenuhi kriteria acces (8). Booklet "Tindakan Higiene Dan Sanitasi Pencegahan Kecacingan" ini sangat tepat digunakan sebagai media promosi kesehatan pada sasaran siswa sekolah dasar, karena ketersediaan sarana dan prasarana serta kondisi atau situasi saat penelitian berlangsung di Indonesia sedang mengalami pandemi Covid-19 termasuk di wilayah Kabupaten Karangasem Provinsi Bali. Berdasarkan hal tersebut maka booklet ini termasuk media yang mudah diakses siswa karena tidak memerlukan peralatan khusus.

Tujuan utama menggunakan Booklet "Tindakan Higiene Dan Sanitasi Pencegahan Kecacingan" ini adalah mejadikan sebagai media promosi kesehatan untuk meningkatkan pengetahuan, sikap dan tindakan dari siswa sebagai sasaran. Booklet ini berisikan materi penting terkait tindakan higiene dan sanitasi pencegahan kecacingan. Adapun materi yang disajikan dalam booklet ini adalah 1) Latar belakang, tujuan, manfaat dari penyusunan booklet ; 2) Jenisjenis cacing sebagai parasit pada manusia termasuk cara penularan, pengaruh pada tubuh, dan cara pencegahan ; 3) Pengobatan kecacingan khususnya terkait dengan kapan waktu yang tepat minum obat cacing ; 4) Tindakan higiene dan sanitasi pencegahan kecacingan mengacu pada program pengendalian faktor risiko cacingan merupakan salah satu kegiatan penanggulangan cacingan yang diatur pada pasal 7 Permenkes RI No 15 Tahun 2017, dimana pengendalian faktor risiko sebagai upaya pencegahan cacingan dapat dilakukan melalui kegiatan menjaga kebersihan perorangan dan menjaga kebersihan lingkungan atau bisa disebut pencegahan kecacingan melalui tindakan higiene dan sanitasi (1). Penyajian booklet ini menggunakan bahasa yang sederhana, singkat dan jelas serta sistematika yang runut dan disertai banyak gambar-gambar di setiap penjelasannya. Penyajian buku seperti di atas sangat menarik sehingga tidak membuat jenuh ketika dibaca dan juga mampu membantu para siswa untuk mengingat kembali materi yang telah sampaikan (9).

Booklet "Tindakan Higiene Dan Sanitasi Pencegahan Kecacingan" ini mampu memberikan pesan dan himbauan yang diharapkan dapat merubah perilaku para siswa melalui tindakan higiene dan sanitasi untuk pencegahan kecacingan ke 
arah yang lebih baik. Adanya himbauan tentang dampak negatif kecacingan terhadap kesehatan, hali ini bisa menjadikan siswa mampu untuk mengubah perilakunya (10). Himbauan yang ada dalam booklet ini adalah berupa ajakan untuk waspada terhadap bahaya yang ditimbulkan kecacingan dan ajakan melakukan upaya pencegahan kecacingan dengan menerapkan tindakan higiene dan sanitasi untuk menghindari hal-hal yang dapat mengakibatkan tertular kecacingan. Berdasarkan hasil penelitian lainnya menyataka bahwa adanya sebuah pesan himbauan dalam sebuah media mampu merubah perilaku siswa menjadi lebih sehat (11).

Keberadaan Booklet "Tindakan Higiene Dan Sanitasi Pencegahan Kecacingan” ini juga disesuaikan dengan tahap perkembangan kognitif, afektif dan psikomotorik siswa kelas III dan kelas IV sekolah dasar. Hal ini didukung oleh penelitian lain yang menyebutkan bahwa siswa kelas IV sekolah dasar memiliki rasa ingin tahu dan minat belajar yang tinggi (12). Kalimat yang disajikan secara sederhana membuat siswa tidak merasa kesulitan untuk memahami kalimat-kalimat yang cukup rumit dalam bacaan (13). Perbandingan antara tulisan dan gambar sangat ideal dimana tulisan yang disajikan dalam booklet ini lebih banyak sekitar 60$70 \%$ daripada gambarnya sekitar 30-40\%, sehingga tidak menjadi masalah dalam memahami materinya oleh siswa kelas III dan IV sekolah dasar di wilayah Desa Tenganan Kabupaten Karangasem.

\section{SIMPULAN}

Berdasarkan hasil pengumpulan data dan pembahasan maka dapat disimpulkan sebagai berikut:

1. Tindakan pencegahan kecacingan pada siswa sekolah dasar di wilayah Desa Tenganan Kabupaten Karangasem diperoleh nilai rata-rata pre-test tindakan higiene 78,33 dan tindakan sanitasi 76,27 pada kelompok kontrol lebih rendah dari nilai rata-rata pre-test kelompok perlakuan dengan nilai tindakan higiene 81,07 dan tindakan sanitasi 82,35. Selisih nilai lebih untuk tindakan higiene sebanyak 2,74 (3,50\%) dan selisih nilai lebih untuk tindakan sanitasi sebanyak 6,08 $(7,97 \%)$.

2. Tindakan pencegahan kecacingan pada siswa sekolah dasar di wilayah Desa Tenganan Kabupaten Karangasem diperoleh nilai rata-rata pos-test tindakan higiene 83,23 dan tindakan sanitasi 81,37 pada kelompok kontrol lebih 
rendah dari nilai rata-rata pos-test kelompok perlakuan dengan nilai tindakan higiene 88,33 dan tindakan sanitasi 88,23 . Selisih nilai lebih untuk tindakan higiene sebanyak 5,1 $(6,13)$ dan selisih nilai lebih untuk tindakan sanitasi sebanyak $6,96(8,55 \%)$.

3. Ada perbedaan nilai rata-rata tindakan pencegahan kecacingan sebelum dan sesudah diberikan booklet tindakan higiene dan sanitasi antara siswa kelompok kontrol dan kelompok perlakuan $0,00<0,05$.

\section{REKOMENDASI}

1. Kepada Kepala Puskesmas Manggis II : untuk meningkatkan tindakan pencegahan penyakit kecacingan pada siswa sekolah dasar di wilayah Desa Tenganan Kabupaten Karangasem, kepada petugas promosi kesehatan puskesmas dapat menggunakan booklet sebagai pilihan utama selain menggunakan cara yang konvensional atau ceramah.

2. Kepada Kepala Sekolah Dasar : untuk meningkatkan tingkat pengetahuan siswa tentang pencegahan penyakit kecacingan "Booklet tindakan Higiene dan Sanitasi Pencegahan Kecacingan" ini dapat digunakan sebagai rujukan dalam memberikan materi mata pelajaran pendidikan jasmani dan kesehatan di sekolah dasar.

\section{DAFTAR PUSTAKA}

1. Kementerian Kesehatan RI. Peraturan Menteri Kesehatan Republik Indonesia Nomor 15 Tahun 2017 Tentang Penanggulangan Cacingan. Jakarta; 2017.

2. Mara D. Sanitation and Health. PLOS Medicine; 2010.

3. Sorensen W. Polyhelminth Infection in East Guatemata School Childreen. J Glob Infectous Dis. 2011;(25-31).

4. Darsana D. Faktor-faktor yang berhubungan dengan kepemilikan jamban keluarga di Desa Jehem Kecamatan Tembuku Kabupaten Bangli Tahun 2012. J Kesehat Lingkung Vol 4 [Internet]. 2014;2:124-33. Available from: http://poltekkes-denpasar.ac.id/files

5. Dewi, Ratna. Hubungan perilaku Higienitas Diri dan Sanitasi Sekolah Dengan Infeksi Soil Transmitted Helminths Pada siswa Kelas III-VI Sekolad Dasar Negeri 5 Delod Peken Tabanan Tahun 2014. E-journal Med. 2017;6.

6. Sutarjana. Hubungan Kebiasaan Cuci 
Tangan Dengan Kejadian Penyakit

Kecacingan di SDN 3 Tenganan

Karangasem Tahun 2019. Skripsi

Prodi D-IV Jur Kesehat Lingkung

Poltekkes Kemenkes Denpasar. 2019;

7. Suiroka I, dkk. Media Pendidikan

Kesehatan. Yogyakarta: Graha Ilmu;

2012.

8. Kholid A. Promosi Kesehatan denga

Pendekatan Teori Perilaku Media,

dan Aplikasi. Jakarta: PT Raja

Grafindo Persada; 2015.

9. Sulistyani NH. Perbedaan Hasil

Belajar Siswa Antara Menggunakan

Media Pockest Book dan Tanpa

Pocket Book pada Materi Kinematika

Gerak Melingkar Kelas X. J Pendidik

Fis. 2013;1 (1):164-72.

10. Atmoko W. Sustainability

Concumption : Perubahan Perilaku

Mengonsumsi Daging. J Ekon dan

Bisnis. 2016;19 (2):249-61.

11. Saputri PE. Dampak komunikasi

Kampanye Global Handwashing Day

dalam Menumbuhkan Perilaku

Mencuci Tangan pada Anak-Anak

(Studi pada Siswa SDN Panggung

Rejo 4 Kecamatan Kepanjen

Kabupaten Malang). Kepanjen

Malang; 2010.

12. Yusuf S. Psikologi Perkembangan
Anak dan Remaja. Bandung: PT.

Remaja Rosdakarya; 2016.

13. Sitepu B. Penulisan Buku Teks

Pelajaran. Bandung: PT. Remaja

Rosdakarya; 2015. 